\title{
Rancang Bangun Sistem Informasi Hasil Perikanan (SIHasper) di Kabupaten Cilacap
}

\author{
Oto Prasadi ${ }^{1}$, Abdul Rohman Supriyono ${ }^{2}$ \\ ${ }^{1}$ Program Studi Teknik Mesin Perikanan, Politeknik Negeri Cilacap \\ ${ }^{2}$ Program Studi Teknik Informatika, Politeknik Negeri Cilacap \\ e-mail: ${ }^{1}$ oto.prasadi@ pnc.ac.id, ${ }^{2}$ a.rohman.sy@ pnc.ac.id
}

Diterima: 8 Oktober 2019; Direvisi: 25 Nopember 2019; Disetujui: 25 Nopember 2019

\begin{abstract}
Abstrak
Data sumberdaya perikanan dan lingkungan di Kabupaten Cilacap belum diolah dan disusun dengan baik yang mengakibatkan kurang atau lambatnya informasi yang diterima oleh para pelaku dalam sistem perikanan, serta pemanfaatan teknologi yang belum maksimal dalam pengolahan data tersebut, sehingga sangat dibutuhkan suatu Sistem Informasi Hasil Perikanan (SIHasper) di Kabupaten Cilacap, agar penyampaian suatu informasi menjadi lebih baik dan dapat diakses dengan cepat oleh seluruh pelaku sistem perikanan dan mempermudah dalam pengambilan suatu keputusan guna pembangunan bidang perikanan selanjutnya. Penelitian ini bertujuan untuk menganalisa sistem hasil perikanan dan merancang sistem teknologi informasi yang terintegrasi berbasis web di Kabupaten Cilacap. Metode yang digunakan dalam pengambilan sampel yaitu studi referensi dengan metode deskriptif komparatif, kemudian metode dalam membangun sistem dilakukan dengan menggunakan The Waterfall Model. Analisis pengembangan sistem informasi bertujuan untuk menghasilkan suatu sistem yang efektif berdasarkan kebutuhan informasi para pengguna dengan membuat database, perancangan user interface (antarmuka) aplikasi, dan menyusun script bahasa pemrograman (coding). Dengan adanya sistem informasi ini dapat memberikan kemudahan kepada pengguna dalam pengelolaan dan pencarian data sumberdaya perikanan, lingkungan, dan teknologi perikanan di Kabupeten Cilacap. Dari hasil verifikasi yang dilakukan menghasilkan sistem dapat bekerja sesuai dengan yang direncanakan, adapun perbaikan akan dilakukan dalam proses pemeliharaan.
\end{abstract}

Kata kunci: Sihasper, Sistem Informasi, Hasil Perikanan Cilacap

\begin{abstract}
Data on fisheries resources and the environmental have not been processed and not effective become slow information received by the actors in the fisheries system, and any problem about resourcess management, so that a Fishery Information System (SIHasper) is needed in Cilacap Regency, so that the delivery of information is better and can be accessed quickly by all actors of the fishery system and makes it easier to make decisions for the development of the next fisheries sector. This study aims to analyze the fisheries system and web design an integrated information technology system in Cilacap Regency. The method used in sampling is a reference study with a comparative descriptive method, then the method of building a system is done using The Waterfall Model. Analysis of information system development aims to produce an effective system based on the information needs of users by creating databases, designing user interfaces, and composing programming language scripts (coding). With this information system can provide convenience to users in the management and search of fisheries resources, environment, and fisheries technology in Cilacap Regency. From the results of verification conducted, the system can work as planned, while repairs will be carried out in the maintenance process.
\end{abstract}

Keywords: Sihasper, Information Systems, Cilacap Fishery Products 


\section{PENDAHULUAN}

Tempat pelelangan ikan (TPI) merupakan bagian dari sarana dan prasarana perikanan tangkap yang terdapat di pelabuhan perikanan, berfungsi meningkatkan nilai ekonomis atau nilai guna dari fasilitas pokok yang dapat menunjang aktivitas di pelabuhan. Tempat pelelangan ikan adalah tempat dimana penjual dan pembeli melakukan transaksi jual beli komoditas perikanan, termasuk ikan dengan cara pelelangan. Pelelangan ikan adalah kegiatan di suatu TPI guna mempertemukan antara penjual dan pembeli, sehingga terjadi lelang harga ikan dari calon pembeli dengan juru bakul yang mereka sepakati bersama[1]. Dengan demikian pelelangan ikan adalah salah satu mata rantai tata niaga komoditas perikanan[2]. Pengoperasian TPI dilakukan oleh Bupati dengan menunjuk KUD sebagai penyelenggara lelang dan menyewa TPI kepada Dinas Kelautan dan Perikanan setempat[3].

Secara garis besar kegiatan yang dilakukan di Tempat Pelelangan Ikan (TPI) dapat diuraikan sebagai berikut: kapal nelayan datang ke TPI setelah melakukan penangkapan ikan dan melelang ikan hasil tangkapannya[4]. Pada saat pelelangan ikan terdapat juru bakul yang mencatat seluruh kegiatan pelelangan ikan yang dicatat di buku. Data yang dicatat di buku diolah menjadi berbagai bentuk laporan untuk memenuhi kebutuhan informasi Tempat Pelelangan Ikan (TPI) dan Pusat atau Unit Pelaksana Teknis (UPT) yang terkait[5]. Kendala yang timbul ketika pendataan dan pengolahan laporan dilakukan secara manual, diantaranya besarnya kemungkinan terjadi kesalahan pada perhitungan retribusi pelelangan ikan, banyaknya bentuk laporan yang harus diselesaikan dalam waktu satu hari, kesulitan melakukan pelaporan pada Pusat atau UPT Tempat Pelelangan Ikan terkait, dan susahnya mendapatkan informasi mengenai jenis ikan yang tertangkap dan harga setiap komoditi ikan/hari[6]. Untuk mengatasi permasalahan yang terjadi, diperlukan metode penyediaan informasi yang memudahkan Tempat Pelelangan Ikan (TPI) dalam pembuatan laporan dan mudah diakses oleh Pemerintah Daerah, Pemerintah Pusat, Unit Pelaksanaan Teknis (UPT) terkait, Dinas Kelautan dan Perikanan (DKP), Pelabuhan Perikanan Samudera Cilacap maupaun oleh masyarakat terkait dan pengguna lainnya yang memerlukan data tersebut. Tujuan penelitian ini untuk menganalisa sistem Hasil Perikanan dan merancang sistem teknologi informasi yang terintegrasi berbasis web di Kabupaten Cilacap.

Berdasarkan penelitian yang berjudul Rancang Bangun Sistem Informasi Pelelangan Ikan Berbasis Web Pada Tempat Pelelangan Ikan Kabupaten Situbondo Jawa Timur, menyatakan bahwa selama ini proses pencatatan data pelelangan ikan khususnya dalam membuat laporan nilai produksi masih menggunakan cara manual, yaitu masih menggunakan media buku. Dari permasalahan tersebut dirancanglah sistem informasi pelelangan ikan berbasis web. Sehingga pihak tempat pelelangan ikan (TPI) dalam hal ini opeator dapat melakukan pencatatan data pelelangan ikan tanpa harus merekapitulasi laporan nilai produksi dengan cara manual. Apabila operator ingin melakukan pelaporan terhadap laporan nilai produksi dan retribusi kepada pihak Dinas Kelautan dan Perikanan maka tidak perlu datang untuk melakukan pelaporan, dikarenakan dalam hal ini Pimpinan Dinas Kelautan dan Perikanan melalui admint dinas hanya membuka halaman laporan pada sistem, kemudian mencetak laporan hasil nilai produksi dari tempat pelelangan ikan (TPI) yang telah ada dalam sistem untuk diberikan kepada pimpinan dinas. Operator tempat pelelangan ikan (TPI) diharuskan melakukan proses pendataan pelelangan ikan terlebih dahulu di website tersebut, setelah itu operator tempat pelelangan ikan (TPI) untuk mendeskripsikan hasil laporan nilai produksi dan retribusi. Dengan adanya sistem informasi pelelangan ikan ini, maka dapat melakukan proses pencatatan pelalangan ikan dengan mudah dan juga memudahkan operator tempat pelelangan ikan (TPI) melaporkan hasil nilai produksi dan retribusi [7]. Sedangkan berdasarkan penelitian yang berjudul Rancang Bangun Aplikasi Pendapatan Pelelangan Ikan Berbasis Web Pada Tempat Pelelangan Ikan (TPI) Pacitan, menyatakan Tempat Pelelangan Ikan (TPI) merupakan lembaga pemerintah daerah yang ada di Kabupaten Pacitan yang menjadi salah satu tempat berkumpulnya para nelayan. Pendapatan yang terjadi setiap hari di TPI saat ini masih menggunakan sistem pendataan yang sangat sederhana, proses pendataan ikan masih dilakukan secara manual dan proses rekapitulasi dilakukan setiap 
kali ada pemasukan ikan dari hasil para nelayan. Dengan adannya permasalahan yang ada di TPI, maka pembuatan system di Kabupaten Pacitan terlaksana[8].

Berdasarkan potensi dari setiap daerah seperti situdondo dan pacitan, terdapat permasalahan-permasalahan yang pada hakikatnya merupakan permasalahan yang sama dengan Kabupaten Cilacap, karena Kabupaten Cilacap memiliki geografis yang sama dengan dua daerah tersebut yang berada di pesisir pantai dengan potensi-potensi sumber daya hayatinya, termasuk bidang perikanan [9]. Sehingga perlunya penelitian Sistem Informasi Hasil Perikanan (SIHasper) di Kabupaten Cilacap untuk mengoptimalkan pemanfaatan sumberdaya perikanan yang berkelanjutan.

\section{METODE PENELITIAN}

Metode dalam membangun sistem ini mengacu pada metode SDLC (System Development Life Cycle) dengan menggunakan pendekatan model Waterfall yaitu sebuah model pengembangan sistem yang bersifat sekuensial dimana setiap tahap harus selesai sebelum beralih ke tahap selanjutnya [10]. Tahapan model ini secara umum terdiri dari 5 tahap yaitu: 1) Analisis kebutuhan, 2) Perancangan, 3) Implementasi, 4) Validasi atau verifikasi dan 5) Pemeliharaan (maintenance).

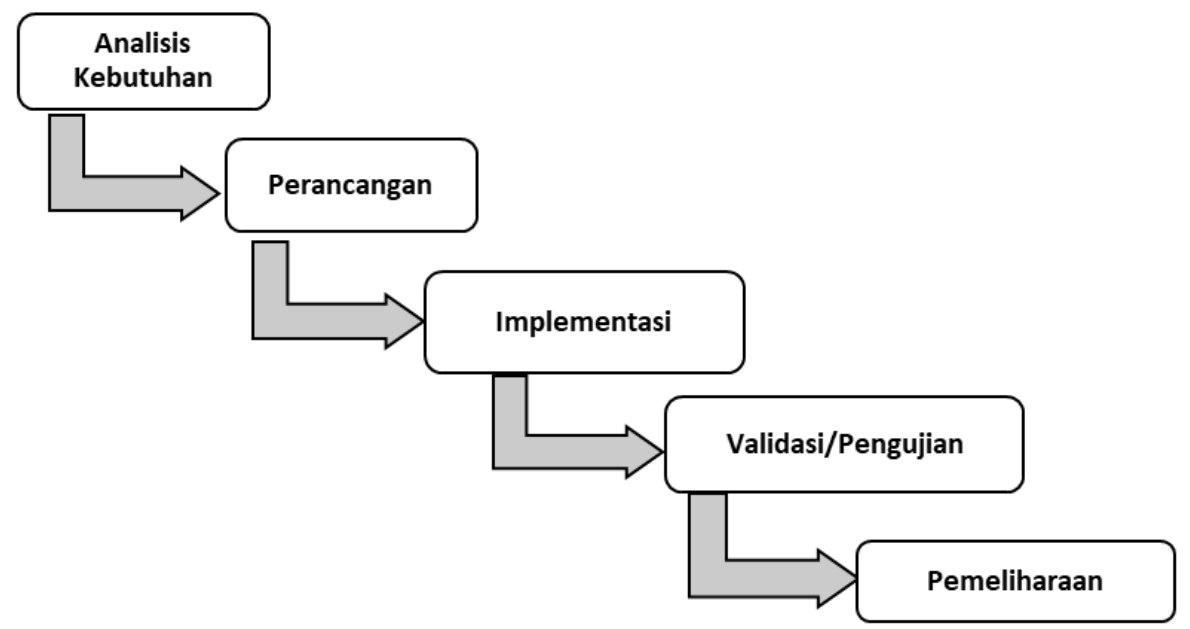

Gambar 1. Tahapan Model Waterfall [11].

1. Analisis Kebutuhan

Tahap analisis kebutuhan merupakan tahap pengumpulan informasi kebutuhan sistem yang akan dibuat sesuai dengan kebutuhan pengguna. Kemudian informasi tersebut didefinisikan ke dalam spesifikasi sistem.

2. Perancangan

Tahap perancangan sistem merupakan lanjutan dari tahap analisis kebutuhan. Secara garis besar perancangan ini dibagi ke dalam 3 bagian, yaitu membuat database, perancangan user interface (antarmuka) aplikasi, dan menyusun script bahasa pemrograman (coding)[12]. Pembuatan database dilakukan menggunakan perangkat lunak DBMS MySQL. User interface adalah tempat bertemunya aplikasi dengan pengguna. User interface dirancang sedemikian rupa untuk mempermudah dan mempercepat pengguna memahami dan menggunakan aplikasi. Perancangan user interface dibuat dalam bentuk sketsa sebagai pedoman dalam tahapan selanjutnya yaitu coding. Bahasa pemrograman dalam coding dibuat sesuai dengan database dan sketsa user interface. Tahapan coding ini berpengaruh secara langsung terhadap tampilan aplikasi karena coding berhubungan dengan sistematika 
tampilan aplikasi. Coding dibuat menggunakan bahasa pemrograman HTML, CSS, PHP, dan JavaScript.

3. Implementasi

Tahap Implementasi sistem adalah tahap mengimplemantasikan rancangan menjadi sebuah program untuk dijadikan suatu sistem yang dapat digunakan.

4. Validasi atau Verifikasi

Tahap Verifikasi sistem ditujukan untuk memastikan program yang dibuat sesuai dengan spesifikasi sistem, sehingga program siap digunakan.

5. Pemeliharaan

Tahap pemeliharaan sistem ditujukan untuk mengetahui kekurangan, memperbaiki, dan menambahkan layanan system[13]

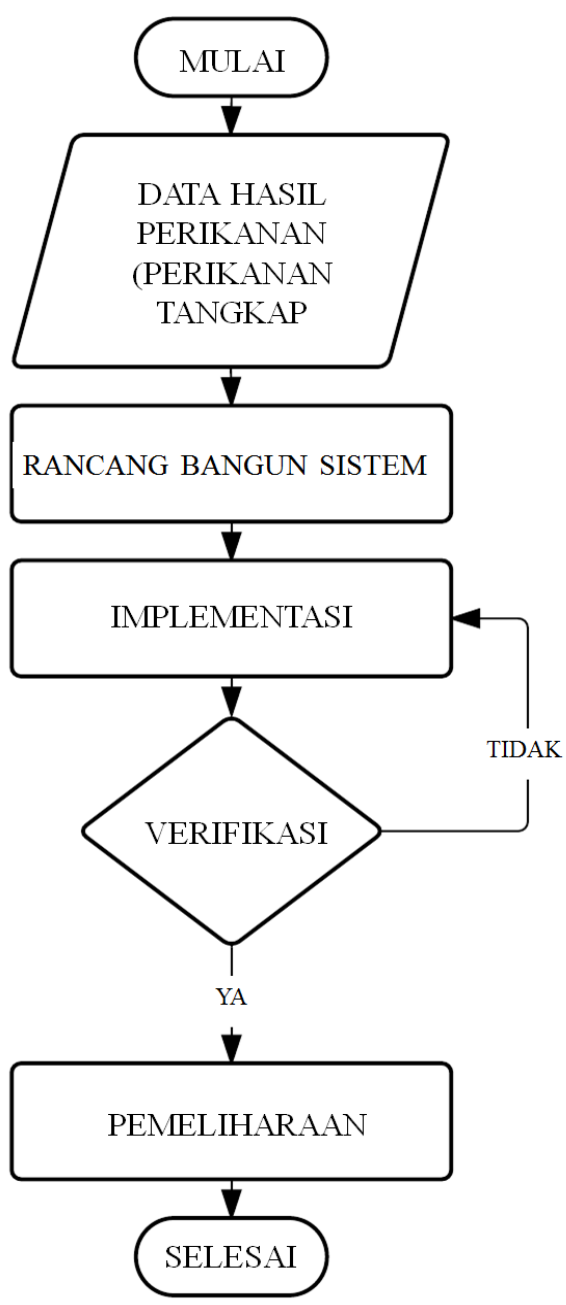

Gambar 2. Diagram Alir Pengolahan dan Analisis Data

Pada Gambar 2 menunjukan bahwa tahap ini menentukan bagaimana kerja sistem informasi yang akan dibuat dalam menyelesaikan masalah. Secara detail tahapan ini menggambarkan rancangan user interface, spesifikasi perangkat keras, perangkat lunak, database, dan menggambarkan bagaimana komponen-komponen tersebut terhubung[14]. Pada Gambar 3 menunjukkan bahwa Perancangan sistem dilakukan dalam tiga bagian, yaitu membuat database, perancangan user interface aplikasi, dan menyusun script bahasa pemrograman (coding) 


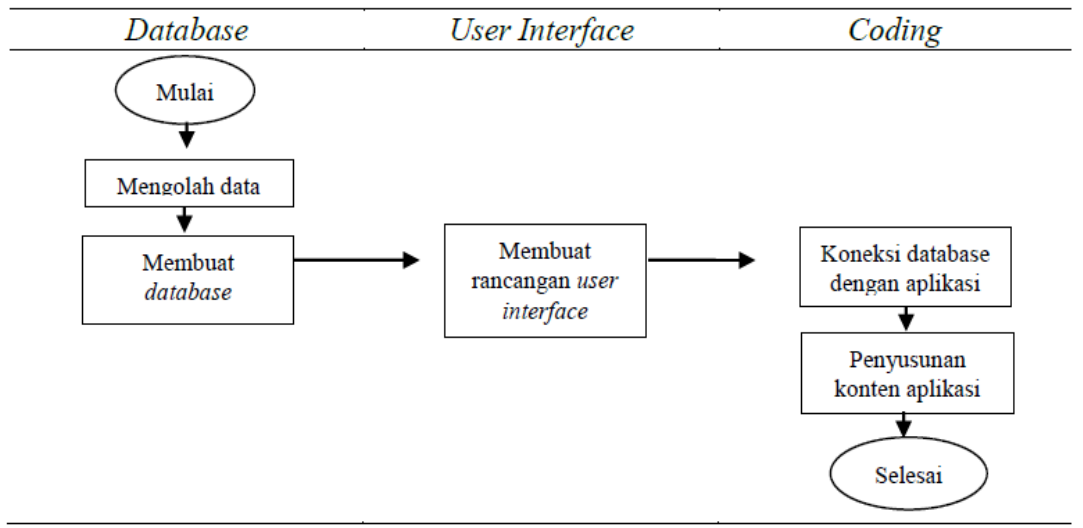

Gambar 3. Perancangan Sistem

Pada Gambar 4 menjelaskan bahwa Pengguna yang membuka aplikasi ini akan langsung dihadapkan pada halaman beranda. Pada halaman beranda terdapat menu navigasi yang tautan pada menu yang terdapat pada aplikasi ini. Pengguna dapat memilih salah satu menu dari ketiga menu yaitu menu sumberdaya perikanan, menu lingkungan, dan menu teknologi. Pengguna tinggal menutup aplikasi ketika sudah selesai menggunakannya.

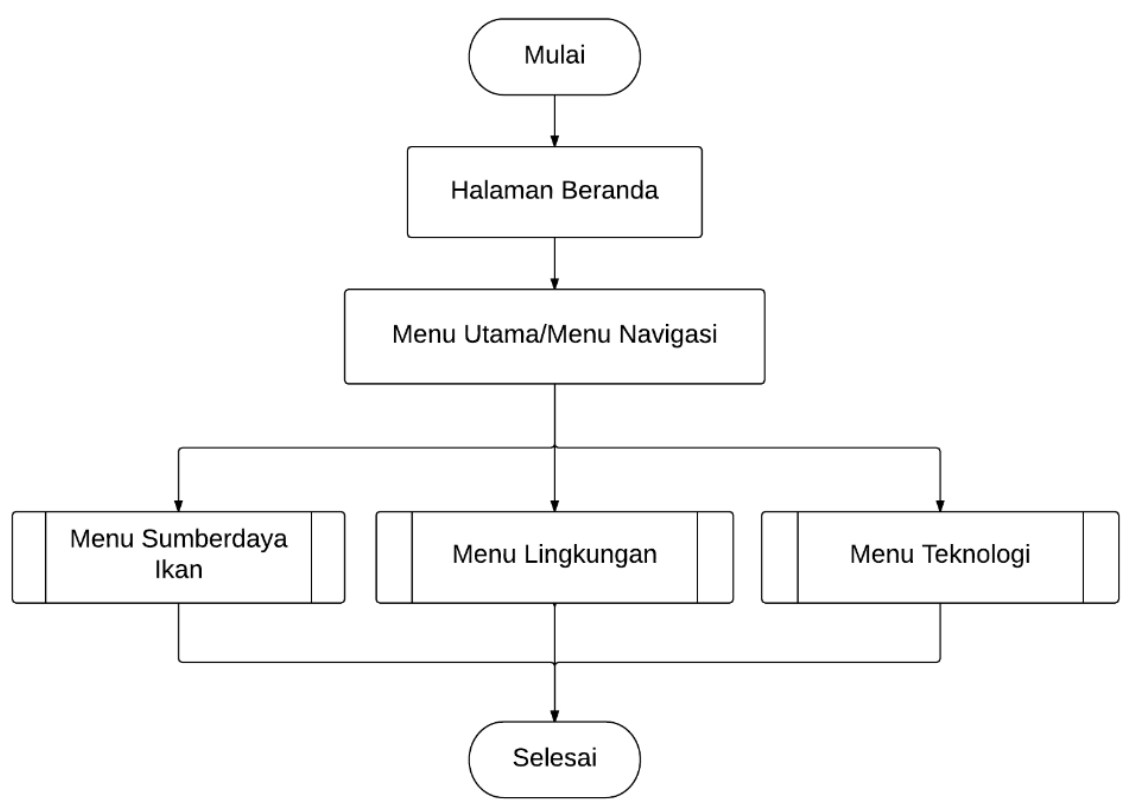

Gambar 4. Alur Penggunaan Aplikas

\section{HASIL DAN PEMBAHASAN}

Aplikasi yang dihasilkan dari penelitian ini diberi nama Sistem Informasi Hasil Perikanan (SIHasper). Maksud dari dibuatnya aplikasi ini lebih kepada penyajian informasi hasil perikanan terutama dalam penyediaan data statistik sumberdaya perikanan, lingkungan, dan teknologi perikanan di Kabupaten Cilacap. Selanjutnya diharapkan aplikasi ini dapat dibuat dan dikembangkan, sehingga dapat bermanfaat bagi pelaku perikanan dan masyarakat di Kabupaten Cilacap.

Halaman beranda (home) berisi informasi tentang aplikasi secara umum. Pengguna aplikasi pertama kali akan disuguhkan halaman ini ketika mengakses website. Isi dari halaman ini 
antara lain header, judul website, logo, menu navigasi, menu utama, kontak, dan footer. Halaman beranda dapat dilihat pada Gambar 5.

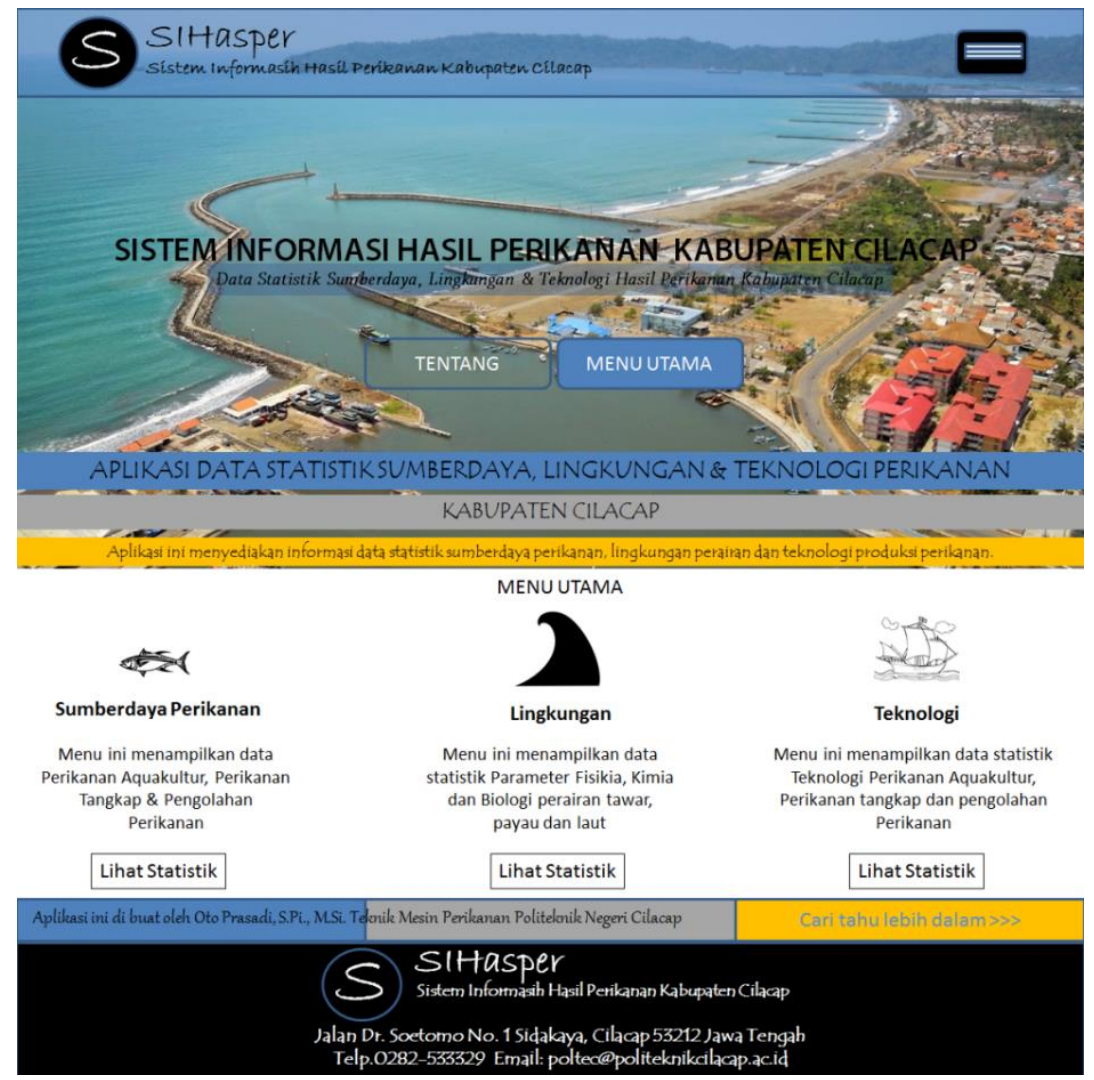

Gambar 5. Halaman Beranda (Home)

Menu navigasi berbentuk tombol terletak di kanan header setiap halaman website. Menu navigasi beranda berisi lima tautan yaitu menu sumberdaya perikanan, menu lingkungan, menu teknologi, tentang dan kontak. Menu sumberdaya perikanan, ligkungan, dan teknologi memiliki sub menu masing-masing. Tautan sub menu akan tampil secara vertikal (dropdown) apabila menu diklik/tap. Tampilan menu navigasi dapat dilihat pada Gambar 6.

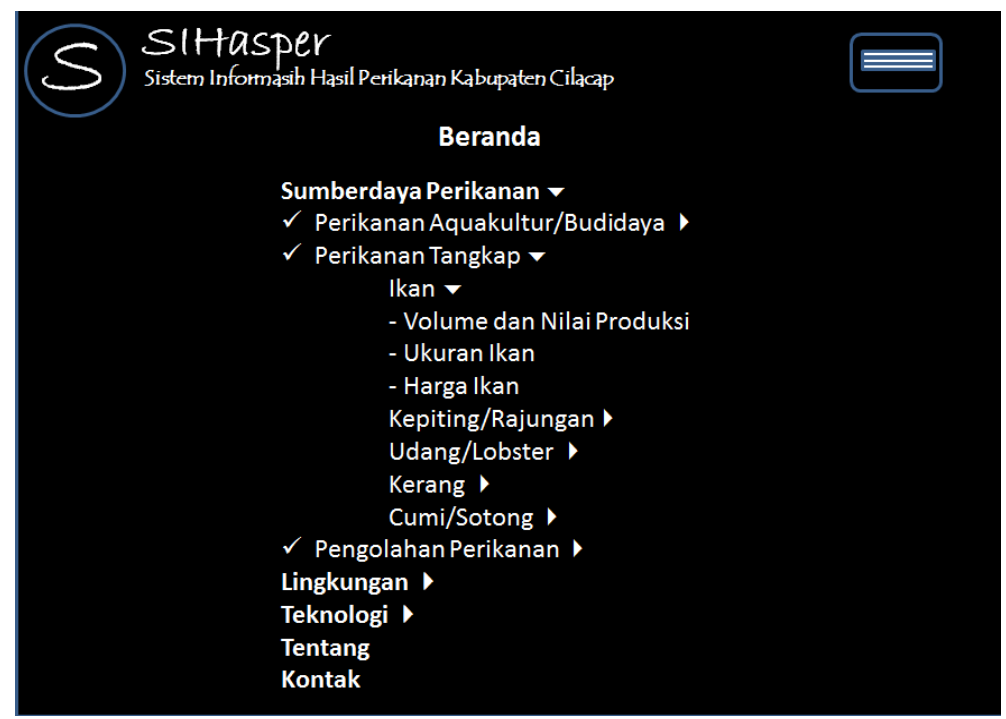

Gambar 6. Menu Navigasi 
Menu sumberdaya perikanan terdiri dari sub menu Perikanan Akuakultur/budidaya, perikanan tangkap dan pengolahan perikanan yang menyajikan informasi mengenai data produksi hasi perikanan di Kabupaten Cilacap. Data tersebut disajikan dalam bentuk tabel dan grafik dinamis. Menu ini berisi tiga sub menu yang masing-masing memiliki tiga sub-sub menu yaitu volume dan nilai produksi ikan, ukuran ikan dan harga ikan. Tampilan sub-sub menu volume dan nilai produksi ikan terdapat pada Gambar 7.
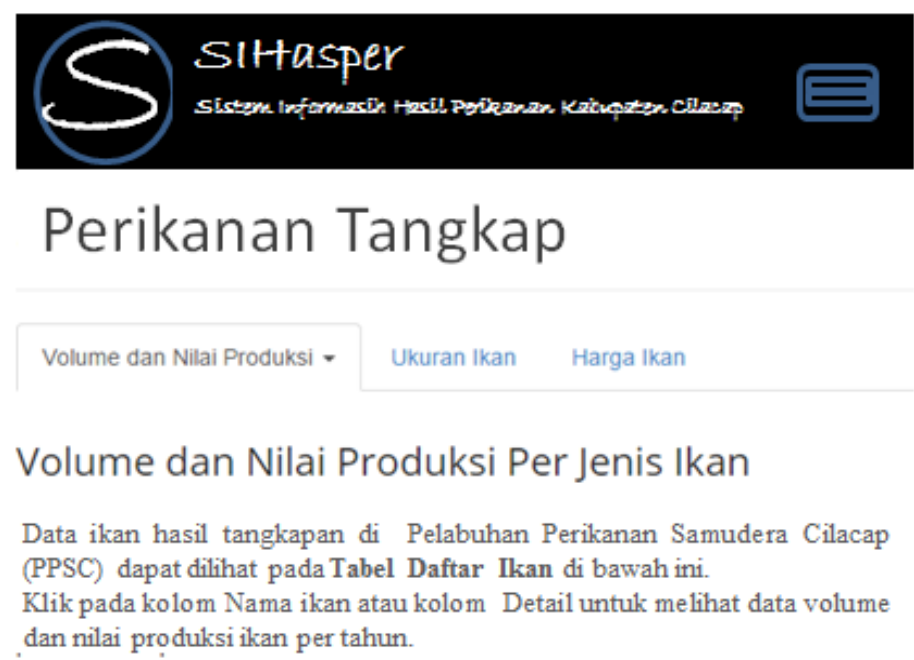

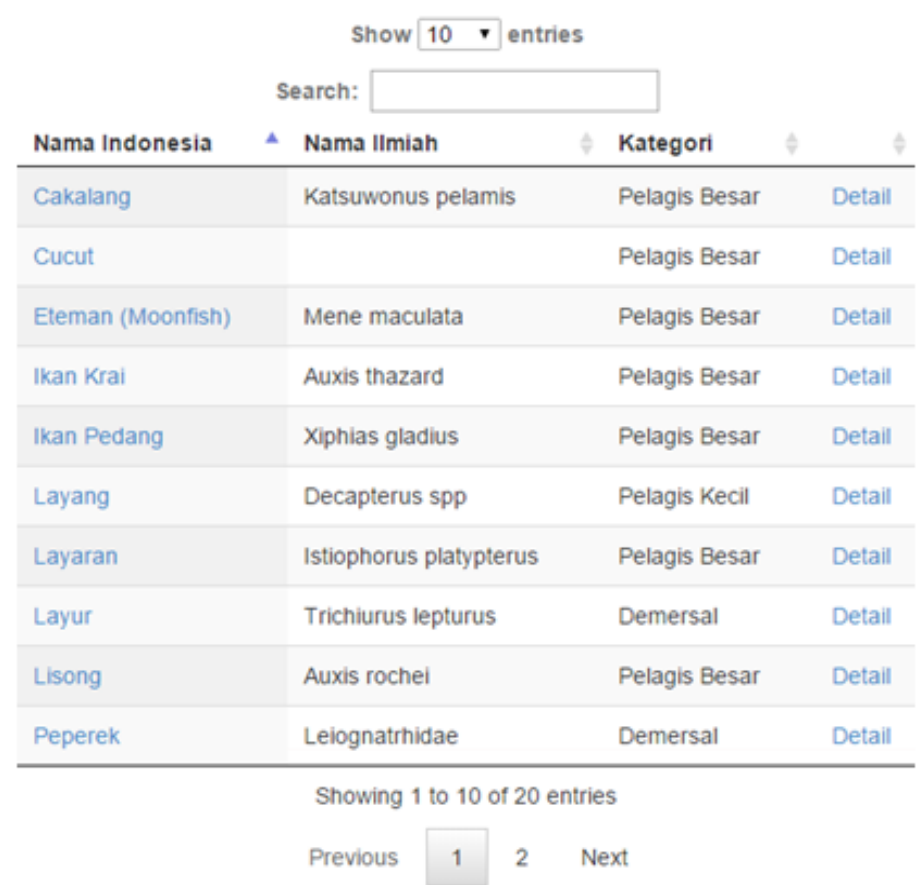

Copyright 92018 , ProgramStudi TekrikMesin Perikanan PolitekrikNegeri Cilacap

Gambar 7. Sub Menu Perikanan Tangkap

Sub-sub menu sumberdaya perikanan berisi volume dan nilai produksi ikan berisi sub-sub-sub menu per tahun dan per jenis ikan. Pengguna dapat memperoleh informasi gambar, deskripsi, volume produksi, dan nilai produksi ikan tertentu per tahun dengan mengklik/tap detail atau nama ikan tertentu pada tabel yang terdapat pada sub-sub-sub menu per jenis ikan. Pengguna kemudian 
akan diarahkan oleh sistem ke halaman detail ikan. Halaman detail ikan menyajikan tabel dan grafik volume dan nilai produksi ikan tertentu per tahun. Dan Menu lingkungan menyajikan data statistik parameter fisika air laut Kabupaten Cilacap. Menu ini terdiri dari tiga sub menu parameter fisika, kimia dan biologi dari perairan tawar, payau maupun laut (asin) yang terdiri dari suhu, salinitas, arus, gelombang, pasang surut, kedalaman dan kecerahan[15]. Data yang ditampilkan dari menu lingkungan per bulan dan per tahun di perairan selatan. Data yang ditampilkan dalam bentuk tab menu pada halaman menu lingkungan. Pengguna dapat mengakses data dengan mengklik/tap tab sub menu parameter fisika/kimia/biologi yang diinginkan.

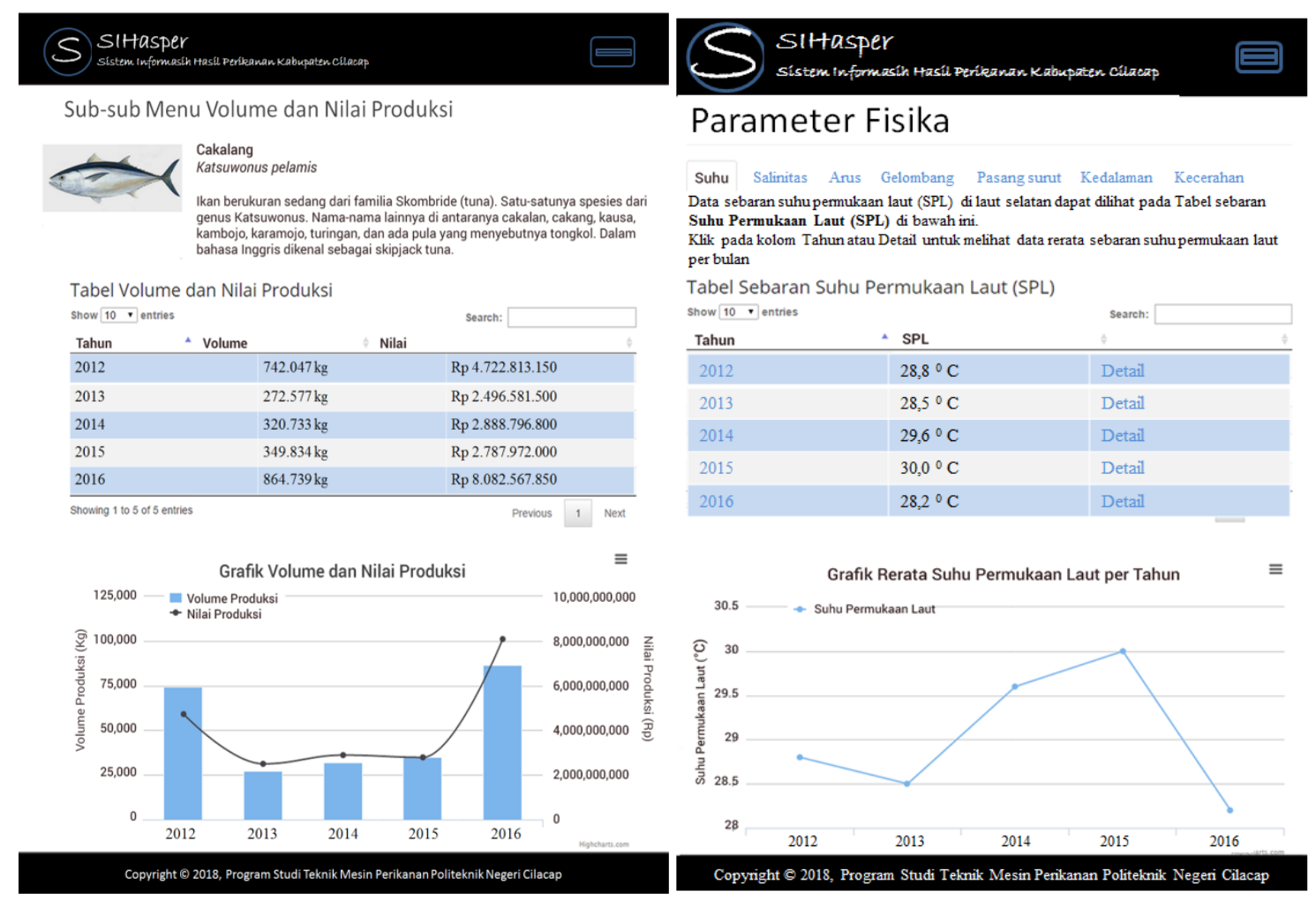

Gambar 8. Sub-sub Menu Perikanan Tangkap dan Sub Menu Parameter Fisik

Menu teknologi terdiri dari tiga sub menu yaitu sub menu teknologi perikanan akuakultur/budidaya, teknologi perikanan tangkap dan teknologi pengolahan perikanan. Dari masing-masing sub menu terdapat sub-sub menu, seperti sub-sub menu dari sub menu teknologi perikanan tangkap yaitu alat penangkapan ikan, nelayan, pelabuhan, tempat pelelangan ikan, pabrik es, dan SPBU. Sub-sub menu kapal perikanan menampilkan tabel kapal perikanan yang berisi data jenis kapal yang beroperasi di perairan selatan Kabupaten Cilacap. Data pada kolom kapal dapat diklik/tap untuk mengetahui jumlah kapal, jumlah pemilik kapal, dan jumlah nelayan yang beroperasi setiap tahun dan Halaman kontak dibuat untuk memberikan pelayanan kepada pengguna yang ingin bertanya atau memberikan saran mengenai aplikasi Sistem Informasi Hasil Perikanan (SIHasper) kepada admin. Halaman ini menampilkan kotak pesan, peta lokasi (Google Map), dan alamat yang dapat dihubungi. Penyusunan script bahasa pemrograman ini diintegrasikan dengan penyedia pemetaan online Google Map, sehingga semua fungsi layanan dari Google Map dapat dipakai pada aplikasi ini. Dan Tampilan menu teknologi menu kontak dapat dilihat pada Gambar 9. 


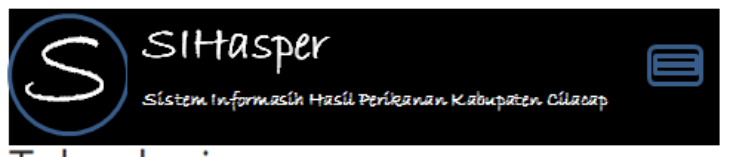

Teknologi

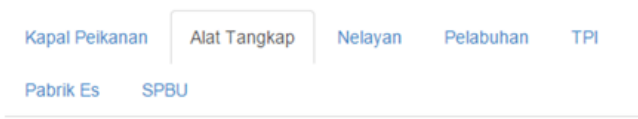

Data alat penangkapan ikan di Perairan Selatan Cilacap dapat dilihat pada Tabel Alat Penangkapan Ikan di bawah ini.

Klik pada kolom Nama API atau kolom Detail untuk melihat data jumlah Alat Penangkapan Ikan per tahun

Tabel Alat Penangkapan Ikan

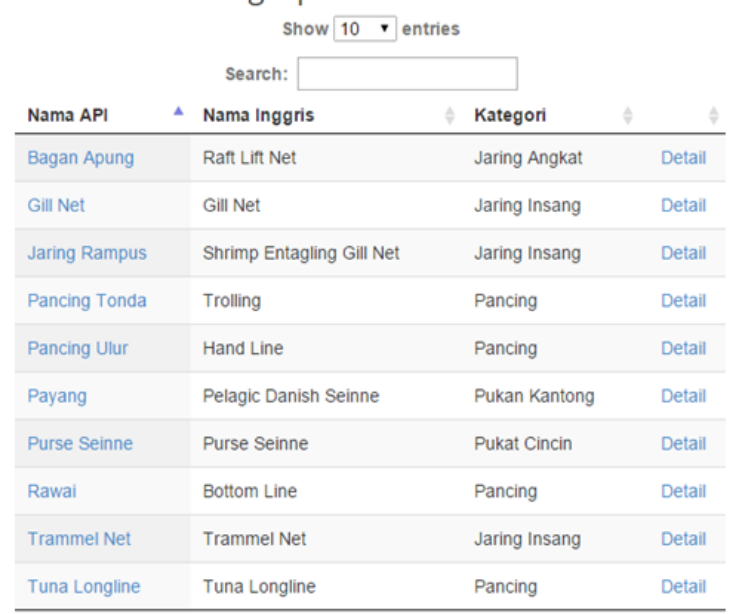

Showing 1 to 10 of 10 entries

$\begin{array}{lll}\text { Previous } & 1 & \text { Next }\end{array}$

Copyright 92018 , Program Studi Teknik Mesin Perikanan Politeknik Negeri Cilacap
Sittasper

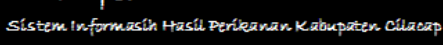

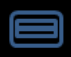

\section{Kontak Kami}

Kami sangat senang apabila mendapatkan masukan dan kritik dari Anda. Isi kotak isian berikut ini untuk mengirim pesan kepada admin. Admin akan merespon dalam beberapa hari.

\begin{tabular}{|l|}
\hline Nama \\
\hline \hline Email \\
\hline \hline Telepon \\
\hline Isi pesan Anda... \\
\\
\end{tabular}

Alamat:

Jurusan Teknik Mesin, Program Studi Teknik Mesin Perikanan,

Politeknik Negeri Cilacap

J1. Dr. Soetomo No.1 Sidakaya, Cilacap 53212 Jawa Tengah, Indonesia

Phone 081288122789, Fax. 0282533329

poltec@politeknikcilacap.ac.id

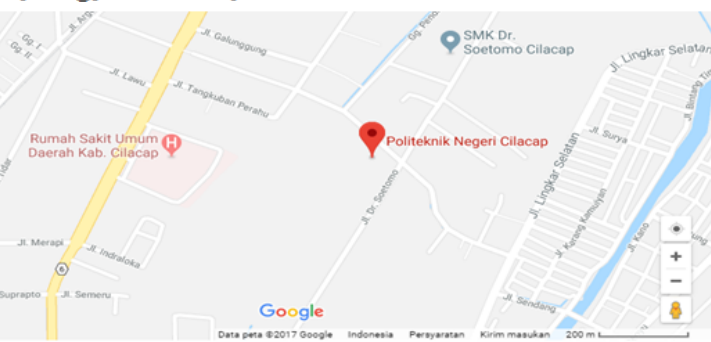

Copyright @ 2018, Program Studi Teknik Mesin Perikanan Politeknik Negeri Cliacap

Gambar 9. Menu Teknologi dan Menu Kontak

\section{KESIMPULAN}

SIHasper menyediakan informasi mengenai data statistik sumberdaya perikanan, lingkungan dan teknologi dibidang perikanan secara mendalam. Sumberdaya perikanan terbagi kedalam tiga sub menu, yaitu 1) Perikanan aquakultur, yang membahas hasil perikanan dari kegiatan budidaya, perikanan tangkap, yang membahas hasil perikanan dari kegiatan penangkapan ikan dilaut dan pengolahan perikanan, yang membahas hasil pengolahan ikan dari kegiatan budidaya dan kegiatan penangkapan ikan, 2) Menu lingkungan di bagi ke dalam tiga sub menu, yaitu perairan tawar, yang membahas parameter kualitas air tawar, perairan payau, yang membahas parameter kualitas air payau dan perairan laut, yang membahas parameter kualitas air laut, 3) Menu teknologi di bagi ke dalam tiga sub menu, yaitu teknologi perikanan aquakultur, yang membahas teknologi di bidang aquakultur, perikanan tangkap, yang membahas teknologi penangkapan ikan dan pengolahan perikanan, yang membahas teknologi pengolahan ikan. Dari masing-masing sub menu di bagi ke dalam beberapa sub-sub menu untuk mempermudah penyampaian informasi di bidang perikanan Kabupaten Cilacap.

\section{SARAN}

Rancang bangun sistem informasi hasil perikanan (SIHasper) masih tahap awal, sehingga 
dalam implementasinya membutuhkan perbaikan-perbaikan disetiap menunya.

\section{UCAPAN TERIMA KASIH}

Terimakasih banyak kepada semua pihak yang sudah membantu dan memberikan dukungan dalam penyelesaian penelitian ini, baik kepada tim atas kekompakkannya, LPPPM Politeknik Negeri Cilacap atas arahannya, Pemerintah Daerah yang sudah memberikan dukungan, terutama kepada Direktorat Riset dan Pengabdian Masyarakat Kemenristekdikti atas kesempatan yang diberikan.

\section{DAFTAR PUSTAKA}

[1] E. Syafruddin, G. Maskie, and Y. P. Pratama, "Kajian Operasional Tempat Pelelangan Ikan (TPI) Dan Kesejahteraan Masyarakat Nelayan (Studi Kasus Desa Watukarung Kecamatan Pringkuku Kabupaten Pacitan),” JIEP, vol. 14, no. 2, pp. 38-57, 2014.

[2] B. T. Simarmata, "Kemampuan Pelelangan Hasil Tangkapan Oleh Pengelola Tempat Pelelangan Ikan Di Pangkalan Pendaratan Ikan Muara Angke, Jakarta," SKRIPSI, p. 139, 2011.

[3] K. Handoyo, "Sistem Informasi Pengelolaan Sumberdaya dan Lingkungan Perikanan Tangkap di Kabupaten Padang Pariaman, Sumatera Barat," SKRIPSI, p. 130, 2011.

[4] R. A. U. Bakarus, "Sistem informasi pengelolaan sumberdaya dan lingkungan perikanan tangkap di palabuhanratu, sukabumi," SKRIPSI, p. 46, 2015.

[5] A. Syarwani, I. Mahyudin, and S. E. Mahreda, "Kajian Pengembangan Tempat Pelelangan Ikan (TPI) Di Sentra Kawasan Pelabuhan Perikanan Muara Kintap Kabupaten Tanah Laut Provinsi Kalimantan Selatan,” EnviroScientea, vol. 12, no. 2, pp. 69-77, 2016.

[6] N. R. Pambudi, "Fungsi Tempat Pelelangan Pelabuhan Ikan Pelabuhan Nusantara Prigi Desa Tasikmadu, Kecamatan Watulimo, Kabupaten Trenggalek," AntroUnairdotnet, vol. VI, no. 3, pp. 428-436, 2017.

[7] R. G. S, I. Much, I. Subroto, and M. Taufik, "Rancang Bangun Sistem Informasi Pelelangan Ikan Berbasis Web Pada Tempat Pelelangan Ikan Kabupaten Situbondo Jawa Timur," J. Transistor Elektro dan Inform., vol. 1, no. 2, pp. 22-36, 2016.

[8] N. Lumaningsih and Sukadi, "Rancang Bangun Aplikasi Pendataan Pelelangan Ikan Berbasis Web Pada TPI (Tempat Pelelangan Ikan) Pacitan," IJNS-Indonesian J. Netw. Secur., pp. 1-7, 2015.

[9] O. Prasadi, "Pemanfaatan Lahan Sempit Sebagai Tempat Budidaya Ikan Cupang Di Mertasing, Cilacap," E-DIMAS, vol. 10, no. 1, pp. 83-88, 2019.

[10] P. Agarwal, A. Singhal, and A. Garg, "SDLC Model Selection Tool and Risk Incorporation," vol. 172, no. 10, pp. 6-10, 2017.

[11] V. Massey, "Comparing Various SDLC Models And The New Proposed Model On The Basis Of Available Methodology," vol. 2, no. 4, pp. 170-177, 2012.

[12] N. Utariningsih, "Sistem Informasi Sumberdaya Perikanan Berbasis Mobile Web (Kasus: Ikan Swanggi Priacanthus tayenus yang di Daratkan di PPP Labuan, Banten).," SKRIPSI, p. 93, 2012.

[13] B. Wardono and U. P. Budi, "Rancang Bangun Kebijakan Pengembangan Budidaya Lele Melalui Pendekatan Model Dinamik," J. Kebijak. Sosek KP, vol. 3, no. 2, pp. 153-163, 2013. 
[14] U. Tangke, "Pemanfaatan sistem informasi perikanan dalam pengelolaan sumberdaya," $J$. Ilm. Agribisnis dan Perikan., vol. 4, no. 2, pp. 52-59, 2011.

[15] O. Prasadi, I. Setyobudiandi, N. A. Butet, and S. Nuryati, "Karakteristik Morfologi Famili Arcidae di Perairan yang Berbeda ( Karangantu dan Labuan , Banten )," J. Teknol. Lingkung., vol. 17, no. 1, pp. 29-36, 2016. 